\title{
Productivity and efficiency index of potassic fertilization in cabbage
}

Thaísa Fernanda Oliveira ${ }^{1} \odot$, Leonardo Angelo de Aquino ${ }^{2} \odot$, Priscila Maria de Aquino²®,

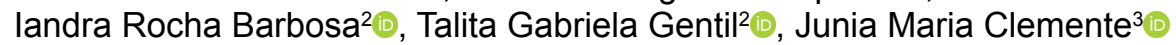

\footnotetext{
1 Universidade de Lavras, Lavras, MG, Brazil. E-mail: thaisafernanda135@gmail.com

2 Universidade federal de Viçosa, Viçosa, MG, Brazil. E-mail: leonardo.aquino@ufv.br; aquino.agronomia@gmail.com; iandra.ufv@gmail.com; talitagabrielagentil@gmail.com

${ }^{3}$ Instituto Federal do Sudeste de Minas Gerais, Manhuaçu, MG, Brazil. E-mail: junia.clemente@gmail.com
}

ABSTRACT: Cabbage presents high growth rate, which demands studies with potassium fertilization due to the high extraction and export of potassium (K). The objective of this study was to evaluate the productivity and efficiency index of $\mathrm{K}$ in the plant and soil in response to doses and sources of this nutrient applied to cabbage crop. Two field experiments were conducted in areas with different soil $\mathrm{K}$ availability. The experiment was designed as randomized blocks with four replicates. The treatments consisted of five doses of $\mathrm{K}_{2} \mathrm{O}\left(0,100,200,400\right.$ and $\left.800 \mathrm{~kg} \mathrm{ha}^{-1}\right)$ applied with Potassium Chloride (KCl) source, and an additional treatment with Potassium Sulphate $\left(\mathrm{K}_{2} \mathrm{SO}_{4}\right)$ source at the dose of $200 \mathrm{~kg} \mathrm{ha}^{-1}$ of $\mathrm{K}_{2} \mathrm{O}$. Cabbage shows high use efficiency and recovery efficiency of $\mathrm{K}$ from soil under low $\mathrm{K}$ availability conditions. High yields may be achieved by applying low $\mathrm{K}$ doses. The crop accumulated high quantities of $\mathrm{K}$ in the shoot, but without having increases on productivity with rising $\mathrm{K}$ doses. Potassium export was most of the accumulated in the shoot in both growing seasons, which shows that cabbage is a high demanding crop. The differences between $\mathrm{K}_{2} \mathrm{SO}_{4}$ and $\mathrm{KCl}$ sources were minimal on productivity and efficiency index of potassium fertilization in cabbage.

Key words: agronomic efficiency; Brassica oleracea; potassium; recovery efficiency

\section{Produtividade e índices de eficiência da adubação potássica em repolho}

RESUMO: O repolho apresenta taxa de crescimento elevada, o que demanda estudos com adubação potássica devido à alta extração e exportação de potássio (K) por essa cultura. Diante disso, objetivou avaliar a produtividade e índices de eficiência de K na planta e no solo em função de doses e fontes desse nutriente aplicado na cultura do repolho. Foram conduzidos dois experimentos a campo em áreas com diferentes disponibilidades de $\mathrm{K}$ no solo. $\mathrm{O}$ delineamento experimental foi em blocos ao acaso com quatro repetições. Os tratamentos consistiram de cinco doses de $\mathrm{K}_{2} \mathrm{O}\left(0,100,200,400 \mathrm{e} 800 \mathrm{~kg} \mathrm{ha}^{-1}\right)$ com a fonte Cloreto de Potássio $(\mathrm{KCl})$, e um tratamento adicional com a fonte Sulfato de Potássio $\left(\mathrm{K}_{2} \mathrm{SO}_{4}\right)$ na dose de $200 \mathrm{~kg} \mathrm{ha}^{-1}$ de $\mathrm{K}_{2} \mathrm{O} . \mathrm{O}$ repolho apresenta alta eficiência de uso e de recuperação de $\mathrm{K}$ do solo quando em condições de menor disponibilidade de $\mathrm{K}$, com a possibilidade de alcançar altas produtividades com aplicação de baixas doses de K. Com o incremento das doses de $\mathrm{K}$ a cultura acumula grandes quantidades do nutriente na parte aérea, porém sem incremento correspondente na produtividade. A exportação de $\mathrm{K}$ foi a maior parte do acumulado na parte aérea, o que evidencia ser o repolho uma planta esgotante do solo. São mínimas as diferenças entre as fontes $\mathrm{K}_{2} \mathrm{SO}_{4}$ e KCl sobre a produtividade e índices de eficiência da adubação potássica no repolho.

Palavras-chave: eficiência agronômica; Brassica oleracea; potássio; eficiência de recuperação 


\section{Introduction}

Cabbage is the main commercial crop from the Brassicaceae family and one of the main vegetables grown in Brazil (Anuário Brasileiro de Hortaliças, 2017). High nutritional value and hybrids adaptation to Brazilian climatic conditions explain its importance (Filgueira, 2012; Correa et al., 2013). It is a vegetable that have high nutrient demand, which must be considered for restitution of nutrients export and maintenance of soil fertility (Cecílio Filho et al., 2013; Correa et al., 2013).

Potassium (K) is among one of the most extracted macronutrients by cabbage (Cecílio Filho et al., 2016). It favors formation and translocation of carbohydrates and the water use efficient by plants; improves products quality and, consequently, the commercial value (Wang et al., 2013; Cecílio Filho et al., 2016).

The uptake of $\mathrm{K}$ by plants is higher than those needed to increase productivity, which is called "luxury consumption" (Correa et al., 2013; Cecílio Filho et al., 2016). In spite of this capacity, an excessive $\mathrm{K}$ fertilization may increase the saline concentration of the soil, reduction on the uptake of other cations, mainly calcium and magnesium, also promoting reduction of crop productivity, and losses by leaching (Trani \& Raij, 1997).

When present in soil solution, $\mathrm{K}$ can move vertically, mainly by drainage water. Due to this movement, $\mathrm{K}$ can be lost by leaching, that is, it is transported to depths beyond those considered explored by roots (Souza et al., 2012). This movement depends mainly on the type of soil, texture, cation exchange capacity (CEC), water and dosage, and fertilizer solubility (Duarte et al., 2013; Sharma \& Sharma, 2013; Fortin et al., 2015).

The increasing crops dependence of fertilizers, their high cost, and finite $\mathrm{K}$ reserves are factors that require constant improvement in the management of $K$ fertilization in vegetable crops. The objective of this study was to evaluate the productivity and efficiency indexes of $\mathrm{K}$ in the plant and soil in response to doses and sources of this nutrient applied to the cabbage crop.

\section{Material and Methods}

Two fields experiments were performed at Federal University of Viçosa (UFV), Campus Rio Paranaíba (Latitude $19^{\circ} 11^{\prime} 39^{\prime \prime} \mathrm{S}$, Longitude $\left.-46^{\circ} 14^{\prime} 37^{\prime \prime} \mathrm{W}\right)$. The altitude of the area is $1,073 \mathrm{~m}$ and the predominant climate is Cwa, according to
Köppen-Geiger classification, which is characterized by a dry season and a well defined rainy season that occurs between October and March.

The experiments were conducted in fields with different $\mathrm{K}$ availability in the soil during two growing seasons (summer and winter). Corn and millet were the previous crops of summer and winter fields, respectively. The dry matter of leaves and stems of corn and millet were removed in order to not provide $\mathrm{K}$ in the successive crops. The soils of both areas are classified as Red-Yellow Latosol with very clayey texture (Embrapa, 2013), whose chemical attributes are presented in Table 1.

The experiments of summer and winter growing seasons were installed on December 11, 2015 and May 13, 2016 and harvested on February 29, 2016 and August 15, 2016, respectively. The cabbage cultivar used was Astrus Plus, F1 hybrid, which shows good compactness (head firmness) and heads with medium to large size, slightly flattened shape and mass ranging from 1.4 to $2.2 \mathrm{~kg}$. The seedlings were produced in styrofoam trays with 200 cells, under protected environment, using an agricultural substrate composed by coconut fiber and vermiculite. For both experiments, the treatments consisted of $0,100,200,400$ and $800 \mathrm{~kg} \mathrm{ha}^{-1}$ of $\mathrm{K}_{2} \mathrm{O}$ applied as Potassium Chloride $(\mathrm{KCl})$. An additional treatment consisted of Potassium Sulphate $\left(\mathrm{K}_{2} \mathrm{SO}_{4}\right)$ at $200 \mathrm{~kg} \mathrm{ha}^{-1}$ of $\mathrm{K}_{2} \mathrm{O}$. These doses encompass and exceed recommended doses of $\mathrm{K}_{2} \mathrm{O}$ for the crop according some authors: 100 to $150 \mathrm{~kg} \mathrm{ha}^{-1}$ (Filgueira, 2012); 180 to 240 $\mathrm{kg} \mathrm{ha}^{-1}$ and complement with fertilization as topdressing with 60 to $120 \mathrm{~kg} \mathrm{ha}^{-1}$ (Trani \& Raij, 1997); and $240 \mathrm{~kg} \mathrm{ha}^{-1}$ (CFSEMG, 1999).

The dose of $200 \mathrm{~kg} \mathrm{ha}^{-1}$ applied as $\mathrm{K}_{2} \mathrm{SO}_{4}$ was tested in order to obtain a comparison between $\mathrm{K}$ sources. Except the control (dose 0 of $\mathrm{K}_{2} \mathrm{O}$ ), the other treatments received $100 \mathrm{~kg} \mathrm{ha}^{-1}$ of $\mathrm{K}_{2} \mathrm{O}$ at seedlings transplant. Therefore, this treatment with $100 \mathrm{~kg} \mathrm{ha}^{-1}$ of $\mathrm{K}_{2} \mathrm{O}$ was performed all at once in the transplant. Treatment with $200 \mathrm{~kg} \mathrm{ha}^{-1}$ of $\mathrm{K}_{2} \mathrm{O}$ was split with $100 \mathrm{~kg} \mathrm{ha}^{-1}$ of $\mathrm{K}_{2} \mathrm{O}$ at the transplant and $100 \mathrm{~kg} \mathrm{ha}^{-1}$ of $\mathrm{K}_{2} \mathrm{O}$ at 10 days after transplant (DAT).

The treatment $400 \mathrm{~kg} \mathrm{ha}^{-1}$ of $\mathrm{K}_{2} \mathrm{O}$ was split with $100 \mathrm{~kg} \mathrm{ha}^{-1}$ of $\mathrm{K}_{2} \mathrm{O}$ at seedlings transplant, $100 \mathrm{~kg} \mathrm{ha}^{-1}$ of $\mathrm{K}_{2} \mathrm{O}$ at 10 DAT, $100 \mathrm{~kg} \mathrm{ha}^{-1}$ of $\mathrm{K}_{2} \mathrm{O}$ at 20 DAT and $100 \mathrm{~kg} \mathrm{ha}^{-1}$ of $\mathrm{K}_{2} \mathrm{O}$ at 30 DAT. The treatment $800 \mathrm{~kg} \mathrm{ha}^{-1}$ of $\mathrm{K}_{2} \mathrm{O}$ received $100 \mathrm{~kg} \mathrm{ha}^{-1}$ of $\mathrm{K}_{2} \mathrm{O}$ at transplant, $100 \mathrm{~kg} \mathrm{ha}^{-1}$ of $\mathrm{K}_{2} \mathrm{O}$ at $10 \mathrm{DAT}, 250 \mathrm{~kg} \mathrm{ha}^{-1}$ of $\mathrm{K}_{2} \mathrm{O}$ at 20 DAT and $350 \mathrm{~kg} \mathrm{ha}^{-1}$ of $\mathrm{K}_{2} \mathrm{O}$ at 30 DAT.

The experiment was designed as randomized blocks with four replicates. The plots presented four rows with six meters length and the ones designed as useful were the two centrals, excluding

Table 1. Soil chemical analysis at 0-20 and 20-40 cm depth in the summer and winter growing seasons.

\begin{tabular}{|c|c|c|c|c|c|c|c|c|c|c|c|c|c|}
\hline \multirow{2}{*}{ Period } & \multirow{2}{*}{$\begin{array}{l}\text { Layer } \\
(\mathrm{cm})\end{array}$} & \multirow{2}{*}{$\begin{array}{l}\mathrm{pH}^{(1)} \\
\mathrm{H}_{2} \mathrm{O}\end{array}$} & \multirow{2}{*}{$\begin{array}{c}\text { P-rem } \\
\left(\mathrm{mg} \mathrm{L}^{-1}\right) \\
\end{array}$} & $P^{(2)}$ & $\mathrm{K}^{+(2)}$ & $S^{(3)}$ & $\mathrm{Ca}^{2+(4)}$ & $\mathrm{Mg}^{2+(4)}$ & $\mathrm{Al}^{3+(4)}$ & $\mathrm{H}+\mathrm{A})^{(5)}$ & \multirow{2}{*}{$\begin{array}{c}\text { O.M. } \\
\left.\text { (dag dm }{ }^{-3}\right)\end{array}$} & \multirow{2}{*}{\multicolumn{2}{|c|}{$\frac{V \quad m}{(\%)}$}} \\
\hline & & & & \multicolumn{3}{|c|}{$\left(\mathrm{mg} \mathrm{dm}^{-3}\right)$} & \multicolumn{4}{|c|}{$\left(\mathrm{cmol}_{\mathrm{c}} \mathrm{dm}^{-3}\right)$} & & & \\
\hline \multirow{2}{*}{ Summer } & $0-20$ & 5.5 & 22.1 & 16.9 & 106.0 & 30.0 & 2.8 & 0.7 & 0.14 & 5.1 & 2.0 & 42.5 & 3.6 \\
\hline & $20-40$ & 5.3 & 17.8 & 8.5 & 76.0 & 35.0 & 2.8 & 0.6 & 0.27 & 4.9 & 1.8 & 42.3 & 7.0 \\
\hline Winter & $20-40$ & 5.7 & 14.3 & 4.2 & 34.0 & 23.0 & 3.6 & 0.9 & 0.00 & 3.5 & 2.5 & 56.7 & 0.0 \\
\hline
\end{tabular}

(1) Ratio 1:2.5; ${ }^{(2)}$ Mehlich 1 extractor; ${ }^{(3)}$ monocalcium phosphate extractor in acetic acid; ${ }^{(4)} \mathrm{KCl} 1 \mathrm{~mol} . \mathrm{L}^{-1}$ extractor; ${ }^{(5)}$ calcium acetate extractor $0.5 \mathrm{~mol} . \mathrm{L}^{-1} / \mathrm{pH} 7.0$. 
$60 \mathrm{~cm}$ from edges. The plants were spaced at $38 \mathrm{~cm}$ between rows and plants for both experiments. The densified spacing was adopted to attain commercially accepted heads with a mean mass of about $1.5 \mathrm{~kg}$, as suggested by Aquino et al. (2005).

The soil preparation consisted of a plowing and two harrowings. Excepting for $\mathrm{K}$, the soil correction acidity and fertilizations were carried out according to soil chemical analysis and crop recommendations. In both experiments, on planting fertilization were applied $100 \mathrm{~kg} \mathrm{ha}^{-1}$ of $\mathrm{N}, 740 \mathrm{~kg} \mathrm{ha}^{-1}$ of $\mathrm{P}_{2} \mathrm{O}_{5}, 2 \mathrm{~kg} \mathrm{ha}^{-1}$ of $\mathrm{B}, 1 \mathrm{~kg} \mathrm{ha}^{-1}$ of $\mathrm{Cu}$ and $5 \mathrm{~kg} \mathrm{ha}^{-1}$ of $\mathrm{Zn}$, which were incorporated into the bed before of the transplant of the seedlings. Coats were performed at 10, 20 and 35 days after transplantation with $50 \mathrm{~kg} \mathrm{ha}^{-1}$ of $\mathrm{N}$ in each application according to the optimum dose suggested by Aquino et al. (2005). Crop treatments, pest control, and conventional sprinkler irrigation were performed according to crop needs. The seedlings were transplanted at 35 days after sowing.

The harvest was performed when heads compactness reached commercial acceptance. Ten uniform plants were harvested from useful plot and separated in heads (commercial part) and external leaves (vegetal remains), that originate the data of productivity and mean fresh mass of heads and external leaves.

After weighing, the heads and external leaves were then washed, grinded and placed in a forced air oven at $65^{\circ} \mathrm{C}$ until reaching constant weigh, in order to determine the dry matter (DM). The K content was determined according to Malavolta et al. (1997).

The $K$ accumulations in each part of plants (head and external leaves) were calculated by the product between DM and $\mathrm{K}$ content for each organ. The total accumulated in the heads and external leaves are nutrients accumulation in the shoot, and the total accumulated only in the heads was the nutrients export.

The $\mathrm{K}$ available in soil ( $\mathrm{mg} \mathrm{dm}^{-3}$ ) after harvest was determined at $0-20$ and $20-40 \mathrm{~cm}$ depths in order to analyze the soil contribution to the $\mathrm{K}$ uptake by plants at both depths. In each plot, 10 simple soil samples were collected and $\mathrm{K}$ content was determined using Mehlich-1 extractor (Tedesco et al., 1995).

The agronomic efficiency (AE) was calculated by the ratio between productivity gain and the applied dose of $\mathrm{K}_{2} \mathrm{O}$, calculated by the following Equation 1 (Fageria, 1998):

$$
\mathrm{AE}=\frac{\mathrm{P}_{\mathrm{CAd}}-\mathrm{P}_{\mathrm{SAd}}}{\mathrm{Q}_{\mathrm{Ap}}}
$$

In which:

$\mathrm{AE} \quad$ - Agronomic Efficiency $\left(\mathrm{kg} \mathrm{kg}^{-1}\right)$;

$P_{\text {cad }}$ - Productivity in the plot with fertilization $\left(\mathrm{kg} \mathrm{ha}^{-1}\right)$;

$\mathrm{P}_{\text {Sad }}$ - Productivity in the plot without fertilization $\left(\mathrm{kg} \mathrm{ha}^{-1}\right)$;

$\mathrm{Q}_{\mathrm{Ap}}$ - Amount of nutrient applied to the soil $\left(\mathrm{kg} \mathrm{ha}^{-1}\right)$.

The recovery efficiency (RE) measures the percentage of $K$ recovered by the plant from the $K$ applied via fertilizer, and was calculated using the following Equation 2 (Fageria, 1998):

$$
\mathrm{RE}=\frac{\left(\mathrm{Q}_{\mathrm{Ad}}-\mathrm{Q}_{\mathrm{NAd}}\right)}{\mathrm{Q}_{\mathrm{Ap}}} \times 100
$$

In which:

RE - Recovery efficiency by plant of the $K$ applied via fertilizer (\%)

$Q_{A d}$ - Amount of nutrient uptake by plant in the fertilized plot (kg ha-1);

$\mathrm{Q}_{\text {NAd }}$ - Amount of nutrient uptake by plant in the nonfertilized plot $\left(\mathrm{kg} \mathrm{ha}^{-1}\right)$;

$Q_{A p}$ - Amount of nutrient applied in the soil $\left(\mathrm{kg} \mathrm{ha}^{-1}\right)$.

The best doses were defined as those that provided 95\% of the maximum productivity estimated by fitted models. $5 \%$ was considered as field losses caused by failures at seedlings transplant, suppressed plants, wheels track of machines and implements, among others. Data were submitted to analysis of variance ( $F$ test for doses, $p<0.05$ ), regression analyzes were performed and equations were fitted according to coefficients of determination. The sources were compared by t test $(p<0.05)$.

\section{Results and Discussion}

Figure $1 \mathrm{~A}$ displays the nonlinear model fitted to cabbage productivity in response to $\mathrm{K}$ doses. Although the soils showed average $\mathrm{K}$ availability, between 1.6 and $3.0 \mathrm{mmol}_{\mathrm{c}} \mathrm{dm}^{-3}$ (Trani \& Raij, 1997), the plants responded to $K$ fertilization (Table 1$)$. The dose to obtain $95 \%$ of the maximum estimated productivity in summer season was $182 \mathrm{~kg} \mathrm{ha}^{-1}$ of $\mathrm{K}_{2} \mathrm{O}$ and in winter season was $168 \mathrm{~kg} \mathrm{ha}^{-1}$ of $\mathrm{K}_{2} \mathrm{O}$, with productivities of 135.59 and $125.64 \mathrm{tha}$ 1 , respectively. These productivities overcome those observed by Moreira et al. (2011) of $56.5 \mathrm{t} \mathrm{ha}^{-1}$, Correa et al. (2013) of 44.5 and $30.0 \mathrm{t} \mathrm{ha}^{-1}$, and Cecilio Filho et al. (2011) of $72.7 \mathrm{t}$ ha ${ }^{1}$. This difference may be related to the use of different plant populations. The cultivation of cabbage with denser spacings, with populations between 56 and 83 thousand plants per hectare, optimize the production by guaranteeing the mean mass of the heads around $1.5 \mathrm{~kg}$ which is considered ideal for the consumer market (Aquino et al., 2005).

Adapted to temperate climates (Filgueira, 2012), the new cabbage cultivars have shown good adaptation to tropical climates, which is reinforced by higher productivities of summer growing season than winter (Figure 1A). Summer season provides longer days with greater availability of solar radiation and water to plants, which are factors that affect their photosynthetic activity, mainly for improving the opening and closure of stomata, thereby, resulting in greater production, translocation and accumulation of photoassimilates (Xue et al., 2016; Guoying et al., 2017).

The leaf contents of $\mathrm{K}$ to obtain $95 \%$ of the maximum estimated productivities were 35.29 and $29.80 \mathrm{~g} \mathrm{~kg}^{-1}$ of DM in the heads, and 24.32 and $20.92 \mathrm{~g} \mathrm{~kg}^{-1}$ of DM in the external leaves, for summer and winter plants, respectively (Figure 1B). They are within adequate range ( 25 to $50 \mathrm{~g} \mathrm{~kg}^{-1}$ of DM) 

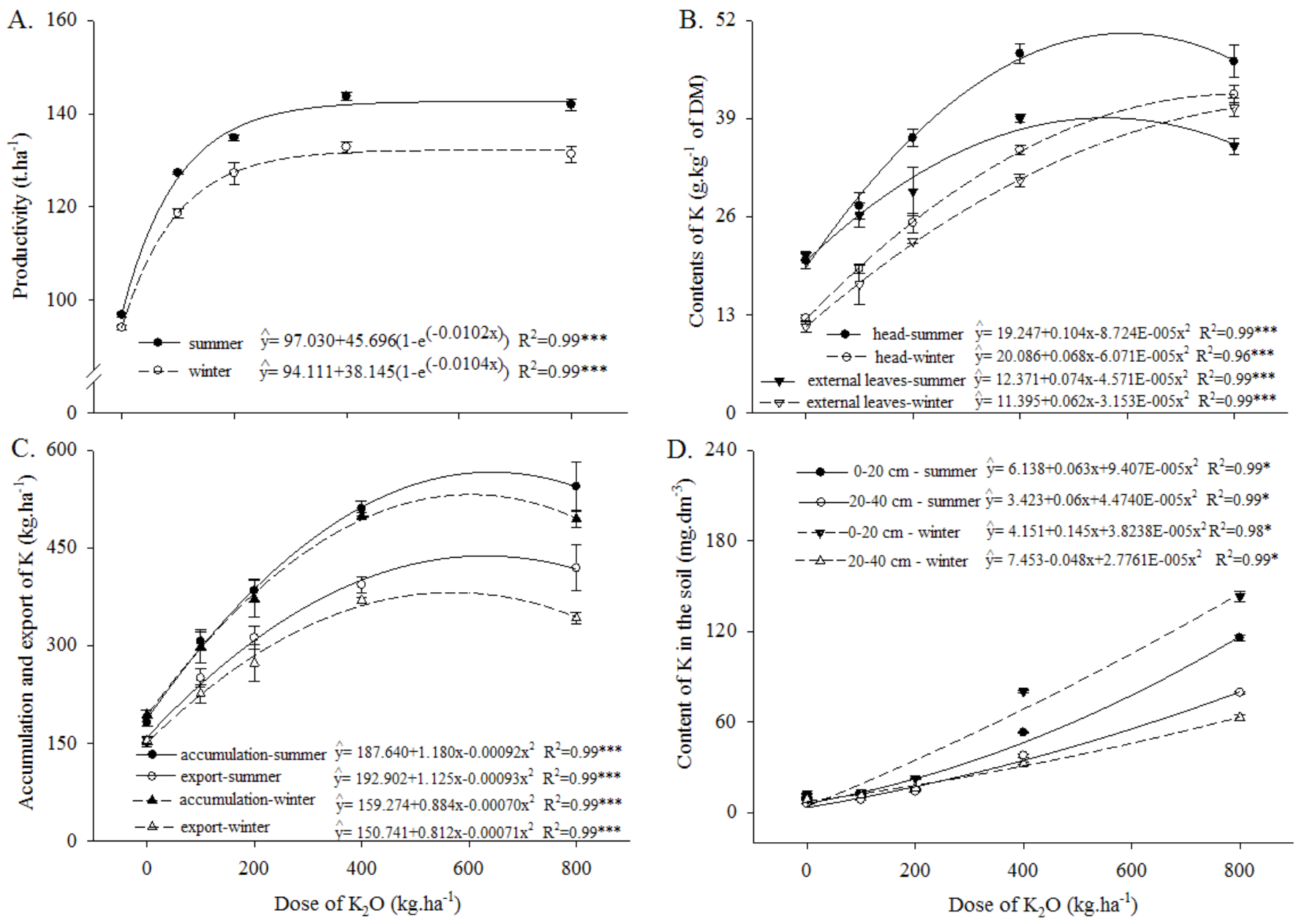

DM: dry matter. ${ }^{*}$ and ${ }^{* * *}$ significant at $5 \%$ and $0.1 \%$, respectively, by $\mathrm{F}$ test.

Figure 1. Productivity of cabbage (A), contents of $K$ in cabbage from the heads and external leaves (B), accumulation of $K$ in the shoot (heads and external leaves), export of $K$ (C) and content of $K$ in the soil after cabbage cultivation (D), submitted to doses of $\mathrm{K}$ in summer and winter growing seasons.

according to Trani \& Raij (1997). The accumulation in the shoot and $\mathrm{K}$ export did not show great divergence regarding summer and winter growing seasons at the dose to reach $95 \%$ of the maximum estimated productivity (Figure $1 \mathrm{C}$ ). In the summer growing season, shoot accumulation was $374.93 \mathrm{~kg}$ $\mathrm{ha}^{-1}$, whereas in winter was $355.66 \mathrm{~kg} \mathrm{ha}^{-1}$.

Increasing doses of $\mathrm{K}$ to cabbage accumulated large amounts of this nutrient in the shoot, without corresponding increases on productivity (Figure $1 \mathrm{~A}$ ). Uptake of $\mathrm{K}$ beyond the crop demand is observed when $\mathrm{K}$ is in a soil with high $\mathrm{K}$ availability, assigning to the cabbage a "luxury consumption" state (Correa et al., 2013; Cecílio filho et al., 2016).

Correa et al. (2013) did not observe increases on productivity with an increasing $\mathrm{K}$ dose and reported a higher concentration of $\mathrm{K}$ in cabbage the higher $\mathrm{KCl}$ dose applied. Increased accumulation of $\mathrm{K}$ can also be considered as a "safety strategy" to enable the plant to better survive a sudden environmental stress condition (Kafkafi, 1990), such as soil water deficit. Thus, in this condition the plant can maintain high $\mathrm{K}^{+}$content in the cytoplasm, mainly to ensure enzymatic activity and osmotic potential (Marques et al., 2014; Pottosin \& Dobrovinskaya, 2014).
Most of the $\mathrm{K}$ was accumulated in the shoot (Figure 1C) for both growing seasons, being $80 \%$ in summer and $75 \%$ in winter, which shows that cabbage is a soil exhausting crop regarding $\mathrm{K}$ and the importance of replacement during cultivations. $K$ accumulation in the cabbage shoot in the two growing seasons (Figure 1C) was close to the total availability of $\mathrm{K}$ in the soil considering the differences in the contents available at $0-20$ and $20-40 \mathrm{~cm}$ depths before (Table 1 ) and after cultivations (Figure 1D).

Potassium that would be accumulated in the whole plant considering also stem and root is not possible to be evaluated, as only external leaves and heads were collected in this study. For the dose of higher productivity (277.8 kg ha-1 of $\mathrm{K}_{2} \mathrm{O}$ ), root and stem contributed with 14.7 and $7.1 \%$, respectively, in the DM partition of the plant according to Moreira et al. (2011). Therefore, in these $22 \%$ of DM, it is possible that $\mathrm{K}$ accumulation by plants is equivalent or higher than the total available at $0-40 \mathrm{~cm}$ depth of soil.

Potassium availability to plants depends on the contents and forms of $\mathrm{K}$ in the soils (non-exchangeable $\mathrm{K}$, exchangeable $\mathrm{K}$ and soluble $\mathrm{K}$ ), which vary with degree of pedogenetic development (Chaves et al., 2015). Researches on Brazilian 
soils has shown that quantities of $\mathrm{K}$ extracted by plants were higher than those estimated by routine extractors regarding the availability of $\mathrm{K}$ in the soil, which suggests good nutrition in $\mathrm{K}$ to plants from non-exchangeable forms of $\mathrm{K}$ in short, medium and long term (Chaves et al., 2015; Manning et al., 2017).

In addition to the fact that plants can access $K$ forms that most of the usual extractors do not quantify (Wang et al., 2011; Chaves et al., 2015), $\mathrm{K}$ from deeper layers may contribute (Souza et al., 2012), and, in this case, layers beyond $40 \mathrm{~cm}$ are analyzed. Deeper soils, such as Latosols and intensive agriculture regions with application of high doses of fertilizers, and deeper layers are considered nutrient reserves for plants because $\mathrm{K}$ is more susceptible to leaching (Liao et al., 2013; Sharma \& Sharma, 2013; Fortin et al., 2015)

The recovery efficiency (RE) reflects the percentage of the applied nutrient that plants uptake (Figure $2 \mathrm{~A}$ ) and presented a linear decrease with increasing $\mathrm{K}_{2} \mathrm{O}$ doses for both growing seasons, that is, the efficiency of nutrient uptake reduces when nutrient availability is higher than crop demand. To obtain $95 \%$ of the maximum estimated productivity the RE was $128 \%$ and $109 \%$ in summer and winter growing seasons, respectively (Figure $2 \mathrm{~A}$ ).

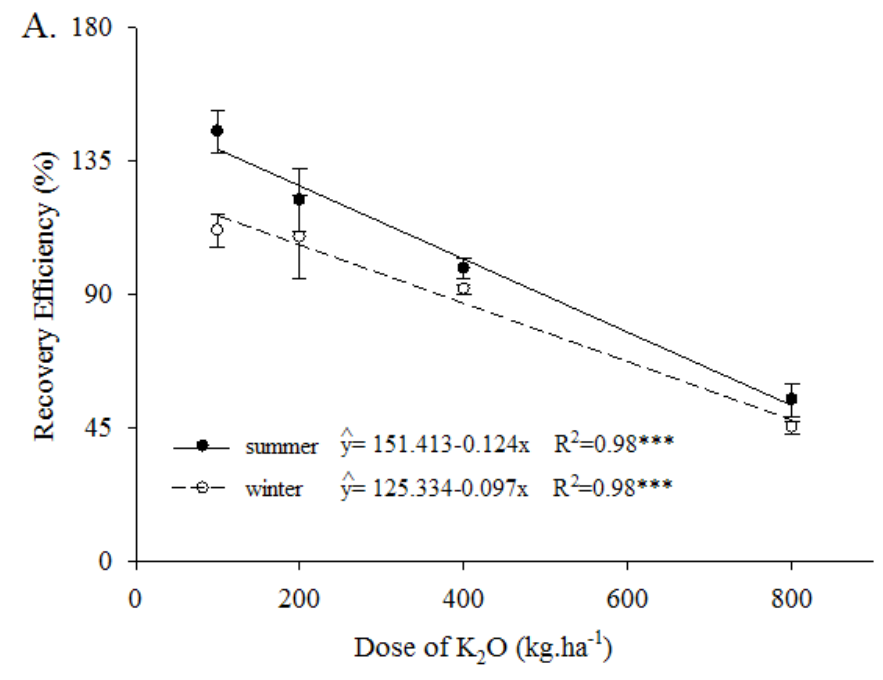

*** significant at $0.1 \%$ by $\mathrm{F}$ test.

Figure 2. Recovery efficiency (A) and Agronomic efficiency summer and winter growing seasons.

Table 2. Productivity, contents and efficiency index of $\mathrm{K}$ fertilization in cabbage, cultivar Astrus Plus, submitted to the sources of $\mathrm{KCl}$ and $\mathrm{K}_{2} \mathrm{SO}_{4}$ at $200 \mathrm{~kg} \mathrm{ha}^{-1}$ of $\mathrm{K}_{2} \mathrm{O}$, in summer and winter growing seasons.

\begin{tabular}{|c|c|c|c|c|}
\hline & \multicolumn{2}{|c|}{ Summer } & \multicolumn{2}{|c|}{ Winter } \\
\hline & $\mathrm{KCl}$ & $\mathrm{K}_{2} \mathrm{SO}_{4}$ & $\mathrm{KCl}$ & $\mathrm{K}_{2} \mathrm{SO}_{4}$ \\
\hline Productivity (t ha-1) & $134.3 \mathrm{a}$ & $134.9 \mathrm{a}$ & $127.5 \mathrm{a}$ & $128.6 \mathrm{a}$ \\
\hline Content of $\mathrm{K}$ in external leaves ( $\mathrm{g} \mathrm{kg}^{-1}$ of DM) & $25.2 \mathrm{~b}$ & 30.9 a & $22.7 \mathrm{a}$ & $24.5 \mathrm{a}$ \\
\hline Content of $\mathrm{K}$ in heads ( $\mathrm{g} \mathrm{kg}^{-1}$ of DM) & 36.5 a & 34.1. a & 29.4 a & $29.4 a$ \\
\hline Extraction ( $\mathrm{kg} \mathrm{ha}^{-1}$ ) & $384.1 \mathrm{a}$ & $389.0 \mathrm{a}$ & $371.0 \mathrm{a}$ & 371.7 a \\
\hline Export $\left(\mathrm{kg} \mathrm{ha}^{-1}\right)$ & $312.1 \mathrm{a}$ & $295.0 \mathrm{a}$ & 272.9 a & $273.1 \mathrm{a}$ \\
\hline Content of $\mathrm{K}$ at $0-20 \mathrm{~cm}\left(\mathrm{mg} \mathrm{dm}^{-3}\right)^{*}$ & 14.7 a & $14.8 \mathrm{a}$ & $22.3 \mathrm{a}$ & $22.7 a$ \\
\hline Content of $\mathrm{K}$ at $20-40 \mathrm{~cm}\left(\mathrm{mg} \mathrm{dm}^{-3}\right)^{*}$ & $13.8 \mathrm{~b}$ & $15.0 \mathrm{a}$ & $16.5 \mathrm{~b}$ & $19.5 \mathrm{a}$ \\
\hline
\end{tabular}

Means followed by the same letter, in the row, do not differ statistically by t test at $5 \%$ probability. ${ }^{*}$ Available $\mathrm{K}$ in soil after cabbage cultivation. 
head and external leaves outside the head; number of leaves (internal and external); diameter and head height according to Correa et al. (2013).

There was no effect of $\mathrm{K}_{2} \mathrm{SO}_{4}$ source on the $\mathrm{KCl}$ source int he study to determine the effect of these sources on growth and yield of kale, celery and lettuce cultivated in hydroponics (Inthichack et al., 2012). Applying $\mathrm{KCl}$ resulted in relatively higher yield of celery, but there was no difference for kale and lettuce, regardless $\mathrm{K}$ dose. In addition, $\mathrm{K}$ supply with $\mathrm{K}_{2} \mathrm{SO}_{4}$ source resulted in higher tips burn compared to $\mathrm{KCl}$, especially at high $\mathrm{K}$ concentrations.

Regarding $\mathrm{K}$ available in the soil after cultivation, it was verified, for both soils, that $\mathrm{K}_{2} \mathrm{SO}_{4}$ presented greater availability of $\mathrm{K}$ at 20-40 cm depth (Table 2). It indicates higher $\mathrm{K}$ leaching with $\mathrm{KCl}$ for layers beyond $40 \mathrm{~cm}$ of soil. Sharma et al. (2013), evaluating the leaching of $\mathrm{K}$ comparing the accompanying anions $\mathrm{Cl}^{-}, \mathrm{SO}_{4}^{-2}, \mathrm{NO}_{3}^{-}$and $\mathrm{H}_{2} \mathrm{PO}_{4}^{-}$, determined that leaching of $\mathrm{KCl}$ is greater than $\mathrm{K}_{2} \mathrm{SO}_{4}$, following the order $\mathrm{SO}_{4}^{-2} \leq \mathrm{H}_{2} \mathrm{PO}_{4}^{-}<$ $\mathrm{NO}_{3}^{-}=\mathrm{Cl}^{-}$.

\section{Conclusions}

Cabbage presents high use and recovery efficiencies of $\mathrm{K}$ from the soil when under low $\mathrm{K}$ availability, possibility reaching high yields by applying low $K$ doses.

Cabbage accumulates large amounts of $K$ in the shoot, but without having a corresponding increase on yield with high $\mathrm{K}$ doses.

Most of the $\mathrm{K}$ is accumulated in the shoot in both growing seasons, which shows that cabbage is a soil-exhausting plant.

The differences between $\mathrm{K}_{2} \mathrm{SO}_{4}$ and $\mathrm{KCl}$ sources are minimal on productivity and efficiency index of potassic fertilization for cabbage.

\section{Acknowledgments}

The authors would like to thank CNPq, CAPES and FAPEMIG for their financial support for research, and to CAPES for the master's scholarship granted to the first author and CNPq for the research productivity scholarship of the second author.

\section{Literature Cited}

Anuário Brasileiro de Hortaliças. Santa Cruz do Sul: Editora Gazeta Santa Cruz, 2017.60 p.

Aquino, L. A.; Puiatti, M.; Pereira, P. R. G.; Pereira, F. H. F.; Castro, M. R. S.; Ladeira, I. R. Características produtivas do repolho em função de espaçamentos e doses de nitrogênio. Horticultura Brasileira, v.23, n.2, p.266-270, 2005. https://doi.org/10.1590/ S0102-05362005000200020.

Cecílio Filho, A. B.; Cavarianni, R. L.; Castro, J. C. C.; Cortez, J. W. M. Cabbage growth and production in relation to plant density and nitrogen. Agrociencia, v.45, n.5, p.573-82, 2011. http://www.scielo.org.mx/scielo.php?script=sci_abstract\&pid =S1405-31952011000500004. 05 Nov. 2017.
Cecílio Filho, A. B.; Cavarianni, R. L.; Nowaki, R. H. D. Accumulation of macronutrients in cv. 'Astrus' cabbage as influenced by nitrogen dose and plant population. Ciencia e Investigación Agraria, v.43, n.2, p.305-315, 2016. https://doi.org/10.7764/rcia.v43i2.1666.

Cecílio Filho, A. B.; Silva, G. S.; Cortez, J. W. M. Phosphorus fertilization of 'Fuyutoyo' cabbages in phosphorus-rich Eutrustox soil. Chilean Journal of Agricultural Research, v. 3, n.3, p.288-92, 2013. https:// doi.org/10.4067/S0718-58392013000300012.

Chaves, E.; Pedron, F. A.; Melo, V. F.; Dalmolin, R. S. D. Reserva mineral de $\mathrm{K}$ por diferentes métodos em argissolos subtropicais. Revista Brasileira de Ciência do Solo, v.39, n.4, p.1088-1099, 2015. https://doi.org/10.1590/01000683rbcs20140670.

Comissão de Fertilidade do Solo do Estado de Minas Gerais - CFSEMG. Recomendações para o uso de corretivos e fertilizantes em Minas Gerais: 5a Aproximação. Viçosa: Editora UFV, 1999. 359 p.

Correa, C. V.; Cardoso, A. I. I.; Claudio, M. D. T. R. Produção de repolho em função de doses e fontes de potássio em cobertura. Semina: Ciências Agrárias, v.34, n.5, p.2129-2138, 2013. https://doi. org/10.5433/1679-0359.2013v34n5p2129.

Duarte, I. N.; Pereira, H. S.; Korndörfer, G.H. Lixiviação de potássio proveniente do termopotássio. Pesquisa Agropecuária Tropical, v.43, n.2, p.195-200, 2013. https://doi.org/10.1590/S198340632013000200003.

Fageria, N. K. Otimização da eficiência nutricional na produção das culturas. Revista Brasileira de Engenharia Agrícola e Ambiental, v.2, n.1, p.6-16, 1998. https://doi.org/10.1590/1807-1929/ agriambi.v02n01p6-16.

Filgueira, F. A. R. Agrotecnologia moderna na produção e comercialização de hortaliças. Novo manual de olericultura. 3.ed. Viçosa: Editora UFV, 2012. 421p.

Fortin, J. G.; Morais, A.; Anctil, F.; Parent, L. E. SVMLEACH - NK POTATO: A simple software tool to simulate nitrate and potassium co-leaching under potato crop. Computers and Electronics in Agriculture, v.110, n.1, p.259-266, 2015. https:// doi.org/10.1016/j.compag.2014.11.025.

Guoying, L.; Du, Q.; Ming, L. J. Interactive effects of nitrate-ammonium ratios and temperatures on growth, photosynthesis, and nitrogen metabolism of tomato seedlings. Scientia Horticulturae, v.214, n.1, p.41-50, 2017. https://doi.org/10.1016/j.scienta.2016.09.006.

Inthichack, P.; Nishimura, Y.; Fukumoto, Y. Effect of potassium sources and rates on plant growth, mineral absorption, and the incidence of tip burn in cabbage, celery, and lettuce. Horticulture, Environment, and Biotechnology, v.53, n.2, p.135-142. 2012. https://doi.org/10.1007/s13580-012-0126-z.

Kafkafi, $U$. The functions of plant $\mathrm{K}$ in overcoming environmental stress situations. In: Development of K-fertilizer recommendations. Colloquium of International Potash Institute, 22., 1990, Bern. Proceedings... Bern: International Potash Institute, 1990. p.65-77.

Liao, Y. L.; Zheng, S. X.; Nie, J.; Xie, J.; Lu,Y. H.; Qin, X. B. Longterm effect of fertilizer and rice straw on mineral composition and potassium adsorption in a reddish paddy soil. Journal of Integrative Agriculture, v.12, n.4, p.694-710, 2013. https://doi. org/10.1016/S2095-3119(13)60288-9.

Malavolta, E.; Vitti, G. C.; Oliveira, S. A. Avaliação do estado nutricional das plantas. Princípios e aplicações. 2.ed. Piracicaba: Associação Brasileira para Pesquisa da Potassa e do Fosfato, 1997. 319 p. 
Manning, D. A. C.; Baptista J.; Limon, M. S.; Brandt, K. Testing the ability of plants to access potassium from framework silicate minerals. Science of the Total Environment, v.574, n.1, p.476481, 2017. https://doi.org/10.1016/j.scitotenv.2016.09.086.

Marques, D. J.; Broetto, F.; Ferreira, M. M.; Lobato, A. K. S.; Ávila, F. W.; Pereira, F. J. Effect of potassium sources on the antioxidant activity of eggplant. Revista Brasileira de Ciência do Solo, v.38, n.1, p.18361842, 2014. https://doi.org/10.1590/S0100-06832014000600018.

Moreira, M. A.; Vidigal, S. M.; Sediyama, M. A. N.; Santos, M. R. Crescimento e produção de repolho em função de doses de nitrogênio. Horticultura Brasileira, v.29, n.1, p.117-21, 2011. https://doi.org/10.1590/S0102-05362011000100020.

Pottosin, I.; Dobrovinskaya, O. Non-selective cation channels in plasma and vacuolar membranes and their contribution to $\mathrm{K}^{+}$ transport. Journal of Plant Physiology, v.171, n.9, p.732-42, 2014. https://doi.org/10.1016/j.jplph.2013.11.013.

Sharma, V.; Sharma, K. N. Influence of accompanying anions on potassium retention and leaching in potato growing alluvial soils. Pedosphere, v.23, n.4, p.464-471, 2013. https://doi.org/10.1016/ S1002-0160(13)60039-9.

Souza, T. R.; Villas Bôas, R. L.; Quaggio, J. A.; Salomão, L. C.; Foratto, L. C. Dinâmica de nutrientes na solução do solo em pomar fertirrigado de citros. Pesquisa Agropecuária Brasileira, v.47, n.6, p.846-854, 2012. https://doi.org/10.1590/S0100-204X2012000600016.
Tedesco, M. J.; Gianello, C.; Bissani, C. A.; Bohnen, H.; Volkweiss, S. J. Análise de solo, plantas e outros materiais. Porto Alegre: Universidade Federal do Rio Grande do Sul, 1995. 174p.

Trani, P. E.; Raij, B. van. Hortaliças. In: Raij, B. van.; Cantarella, H.; Quaggio, J.A.; Furlani, A.M.C. Recomendações de adubação e calagem para o estado de São Paulo. 2.ed. Campinas: Instituto Agronômico de Campinas, 1997. 285p. (Instituto Agronômico de Campinas. Boletim Técnico, 100)

Wang, H. Y.; Shen, Q. H.; Zhou, J. M.; Wang, J.; Du, C. W.; Chen, X. $\mathrm{Q}$. Plants use alternative strategies to utilize nonexchangeable potassium in minerals. Plant Soil, v.343, n.1-2, p.209-220, 2011. https://doi.org/10.1007/s11104-011-0726-x.

Wang, M.; Zheng, Q.; Shen, Q.; Guo, S. Review: The Critical Role of Potassium in Plant Stress Response. International Journal of Molecular Sciences, v.14, n.1, p.7370-7390, 2013. https://doi. org/10.3390/ijms14047370.

Xue, W.; Otieno, D.; Ko, J.; Werner, C.; Tenhunen, J. Conditional variations in temperature response of photosynthesis, mesophyll and stomatal control of water use in rice and winter wheat. Field Crops Research, v.199, n.1, p.77-88, 2016. https://doi. org/10.1016/j.fcr.2016.09.016. 